\title{
Proses Pembentukan Karakter Disiplin Tanggung Jawab dan Kemandirian melalui Program Pembiasaan dan Keteladanan di TK A Kota Cimahi
}

\author{
Amanda Nur Apriana*, Nan Rahmiwati \\ Prodi Pendidikan Guru PAUD, Fakultas Tarbiyah dan Keguruan, Universitas Islam \\ Bandung, Indonesia. \\ *amandaapriana8876@gmail.com ,nanrahmiwati@gmail.com
}

\begin{abstract}
This research is motivated by the process of forming the character of discipline, responsibility and independence through the habituation and exemplary program in Kindergarten A. One of the keys is to inculcate habituation and example to students so that character building is related to creating positive things. Therefore, the formation of character is very important to change attitudes through habituation and exemplary. Based on the results of observations made, the character formation of students in TK A Enough. The problems examined in this study, namely how to prepare the process of forming the character of discipline, responsibility and independence through the habituation and exemplary program. Related to this problem, this study aims to identify the steps that the data do through the habituation and exemplary program. This research method uses descriptive analytic method. The data collection was carried out using observation interview techniques and documentation studies. The results of this study indicate that the formation of the character of discipline, responsibility and independence through the habituation and exemplary program carried out by schools by implementing and modeling is carried out at various stages. In character building in Kindergarten A, it can be successful or fulfill development as expected.
\end{abstract}

Keywords: Process of Forming Disciplinary Character, Responsibility and Independence, Habit, Modeling.

Abstrak. Penelitian ini dilatarbelakangi oleh proses pembentukan karakter disiplin, Tanggung Jawab dan kemandirian melalui program pembiasaan dan keteladan di Tk A. salah satu kuncinya adalah menanamkan pembiasaan dan keteladanan kepada peserta didik agar dalam pembentukan karakter kaitannya dengan menciptakan hal yang positif. Oleh sebab itu, pembentukan karakter sangatlah penting untuk merubah sikap melalui pembiasaan dan keteladanan. Berdasarkan hasil observasi yang dilakukan, pembentukan karakter peserta didik di TK A Cukup. Permasalahan yang dikaji dalam penelitian ini, yaitu bagaimana persiapan proses pembentukan karakter disiplin, Tanggung Jawab dan kemandirian melalui program pembiasaan dan keteladanan. Berkaitan dengan masalah tersebut, penelitian ini bertujuan untuk mengidentifikasi langkahlangkah yang dilakukan data melalui program pembiasaan dan keteladan. Metode penelitian ini menggunakan metode deskriptif analitik. Pengumpulan data yang dilakukan pun dengan menggunakan teknik wawancara observasi dan studi dokumentasi. Hasil penelitian ini menunjukkan bahwa pembentukan karakter disiplin, Tanggung Jawab dan kemandirian melalui program pembiasaan dan keteladan yang dilakukan sekolah dengan cara menerapkan dan mencontohkan ini dilakukan dengan berbagai tahapan. Dalam pembentukan karakter di TK A dapat berhasil dengan baik atau memenuhi berkembang sesuai harapan.

Kata Kunci : Proses Pembentukan Karakter Disiplin, Tanggung Jawab dan Kemandirian, Pembiasaan, Keteladanan. 


\section{A. Pendahuluan}

Pendidikan hingga kini masih dipercaya sebagai media yang sangat ampuh dalam membangun kecerdasan sekaligus kepribadian anak manusia menjadi lebih baik. Pada pendidikan anak usia dini sangat perlu untuk diperhatikan dan menerapkan pendidikan karakter demi masa depan anak-anak Indonesia yang lebih baik. Dengan pendidikan karakter itu diharapkan pula anakanak tumbuh paripurna atau sempurna. Pada usia 0-6 tahun, pada periode ini otak anak sedang berkembang sangat pesat, mereka akan mampu menyerap dengan cepat segala sesuatu yang dilihat dan dengarnya. Oleh karena itu, pendidikan secara terus-menerus dibangun dan dikembangkan agar dari proses pelaksanaannya menghasilkan generasi yang diharapkan. Demikian pula dengan pendidikan karakter anak usia dini agar kedepannya menjadi penerus bangsa yang baik. menurut John Dewey menyebutkan bahwa pendidikan ialah salah satu proses pembaharuan makna pengalaman. Sedangkan menurut H. Home, pendidikan merupakan proses yang terjadi turun-menurun dari penyesuaian yang lebih tinggi bagi makhluk yang telah berkembang secara fisik dan mental, yang bebas dan sadar kepada Tuhan, seperti termanifestasi dari alam sekitar, intelektual, emosional, dan kemanusiaan dari manusia.

Proses pembentukan karakter disiplin, tanggung jawab serta kemandirian memiliki perbandingan disetiap lembaga lainnya, namun dalam pembentukan karakter tersebut tentunya terdapat perbedaan dalam penerapan yang diberikan oleh para guru. Sedangkan pendidikan karakter merupakan upaya sekolah tersebut untuk mendidik para peserta didik agar memahami cara mencintai dan melakukan kebaikan yang bertujuan untuk menerapkan etika melalui pendalaman pembiasaan dan keteladanan. Pendidikan karakter bukan sekedar mendidik benar atau salah tetapi ini adalah proses menerapkan pembiasaan dan keteladanan tentang perilaku yang baik sehingga peserta didik dapat memahami merasakan dan selalu berperilaku baik dilingkungannya sehingga terbentuklah karakter yang baik pula. Proses persiapan pendidikan dalam bahasa sederhana ialah bagaimana peserta didik lebih baik dalam pengetahuan, sikap, maupun keterampilan. Namun dalam praktiknya lebih ditekankan pada aspek prestasi akademik sehingga sekolah mengabaikan karakter para peserta didik. Walaupun dalam teori sosiologi menyebutkan bahwa pembentukan karakter menjadi tugas utama keluarga tetapi sekolah pun ikut bertanggung jawab terhadap kegagalan dalam pembentukan karakter di kalangan para peserta didik.Tujuan Penelitian : a. Memperoleh data melalui dokumen yang dilakukan pembentukan karakter disiplin, tanggung jawab dan kemandirian,b. Untuk mengidentifikasi langkah-langkah yang dilakukan siapa data melalui dokumen RPPH, c. Memperoleh metode dan teknik yang digunakan dalam pemebntukan karakter disiplin, tanggung jawab dan kemandirian.

\section{B. Landasan Teori}

\section{Karakter}

Ryan \& Lickona seperti yang dikutip Sri lestari (2018:262) mengungkapkan bahwa nilai dasar yang menjadi landasan dalam membangun karakter adalah hormat (respect). Hormat tersebut mancakup respek pada diri sendiri, orang lain, semua bentuk kehidupan maupun lingkungan yang mempertahankannya. Dengan memiliki hormat, maka individu memandang dirinya maupun orang lain sebagi sesuatu yang berharga dan memiliki hak yang sederajat. Karakter terbentuk dari kebiasaan. Kebiasaan saat anak-anak biasanya bertahan sampai masa remaja.

\section{Disiplin}

Kedisiplinan merupakan suatu hal yang mutlak dalam kehidupan manusia, karena seorang manusia tanpa disiplin yang kuat akan membahayakan pada dirinya dan manusia lainnya bahkan alam sekitarnya (Hani, 2008 : 17). Kemudian menurut depdiknas (2007:17) perilaku disiplin adalah kemampuan seorang anak untuk menyeimbangkan antara pola pikir dan pola tindakan dikarenakan adanya situasi dan kondisi tertentu dengan pembatasan peraturan yang diperlukan terhadap dirinya oleh lingkungan dimana individu berada. Selanjutnya menurut Yaumi (2014 : 92 ) disiplin adalah tindakan yang yang menunjukkan perilaku tertib dan patuh pada berbagai ketentuan dan peraturan yang berlaku. 


\section{Tanggung Jawab}

Tanggung jawab itu bersifat kodrati, artinya sudah menjadi bagian kehidupan manusia, bahwa setiap manusia pasti diberi konsep tanggung jawab. Tanggung jawab juga berarti berbuat sebagai perwujudan kesadaran akan kewajiban. Sikap tanggung jawab untuk anak usia dini termasuk pada salah satu aspek perkembangan sosial emosioanal.

\section{Kemandirian}

Kemandirian adalah suatu upaya yang dilakukan dan dimaksudkan untuk melatih anak dalam memecahkan masalahnya.Dapat di simpulkan pengertian kemandirian adalah memiliki kepercayaan dalam diri mengerjakan tugas-tugasnya bertanggung jawab.

\section{Pembiasaan}

Pembiasaan merupakan salah satu metode pendidikan yang sangat penting, terutama bagi anak-anak. Mereka belum menginsafi apa yang disebut baik dan buruk dalam arti Susila. Mereka juga belum mempunyai kewajiban-kewajiban yang harus dikerjakan seperti pada orang dewasa. Sehingga mereka perlu dibiasakan dengan tingkah laku, keterampilan, kecakapan, dan pola pikir tertentu. Anak perlu dibiasakan pada sesuatu yang baik.

\section{Keteladanan}

Keteladan merupakan tindakan penanaman akhlak yang dilakukan oleh seseorang yang memiliki profesi dengan menghragai ucapan, sikap, dan perilaku sehingga dapat ditiru orang lain yang dilakukan oleh pengajar kepada peserta didik.

\section{Metode Penelitian}

Pada dasarnya penelitian ini dimaksudkan untuk sebagai alat mencapai tujuan penelitian serta untuk mengumpulkan data terkait dengan program pembiasaan dan keteladanan di TK A Kota Cimahi. Berdasarkan permasalahan yang di angkat penelitian ini menggunakan pendekatan deskriptif analitik. Menurut Arifin (2011:140) "penelitian deskriptif analitik adalah suatu proses penelitian yang dilakukan secara wajar dan natural sesuai dengan kondisi objektif dilapangan tanpa adanya manipulasi. Serta jenis data yang dikumpulkan terutama data kualitatif". Dapat disimpulkan bahwa deskriptif analitik merupakan penelitian yang ilmiah dengan menggunakan berbagai metode yang dan hasilnya sesuai dengan kenyataan yang ada di lapangan dengan teknik wawancara, studi dokumentasi dan observasi untuk mendapatkan data yang mendalam, suatu data yang mengandung makna yang sebenarnya.

\section{Hasil dan Pembahasan}

1. Persiapan yang dilakukan untuk pembentukan karakter disiplin,Tanggung Jawab dan kemandirian melalui program pembiasaan dan keteladanan di TK A. Hasil wawancara dan Hasil Studi Dokumentasi

2. Langkah-Langkah yang dilakukan dalam pembentukan karakter disiplin, Tanggung Jawab dan kemandirian Di TK A Kota Cimahi

Hasil Observasi

3. Evaluasi yang digunakan dalam pembentukan karakter disiplin, Tanggung Jawab dan kemandirian Di TK A Kota Cimahi

Hasil wawancara dan Hasil Studi Dokumentasi

\section{Pembahasan}

1. Persiapan yang dilakukan untuk pembentukan karakter disiplin, Tanggung Jawab dan kemandirian melalui program pembiasaan dan keteladanan di TK A. Pembentukan karakter disekolah guru telah menerapkan pembiasaan dan keteladanan peserta didik dari kegiatan awal, kegiatan inti dan kegiatan akhir. Menerapkann bagaimana pembiasaan yang harus dilakukan oleh peserta didik dan guru pun memberikan contoh keteladanan kepada peserta didik datang ke sekolah di sambut oleh guru dan peserta didik mengucapkan salam, berbaris untuk upacara bendera melatih kerapihan agar tertib, bersyair bernafaskan agama untuk melatih karakter agama, merapihkan mainan kembali ditempat semula peserta didik mempunyai rasa Tanggung 
Jawab, disiplin, kemandiriaan dan mentaati aturan bermain, cuci tangan sebelum dan sesudah makan menjaga hidup sehat serta mandiri, berdoa sebelum makan dan minum berbagi dengan teman dan guru, membuang sampah pada tempatnya kesadaran peserta didik, merapihkan kursi ke atas meja setelah sekolah dan salam kepada guru.

2. Langkah-Langkah yang dilakukan dalam pembentukan karakter disiplin, Tanggung Jawab dan kemandirian Di TK A Kota Cimahi

TK A Kota Cimahi dalam pembentukan karakter disiplin, Tanggung Jawab dan kemandirian melalui program pembiasaan dan keteladanan ada beberapa langkahlangkah yang telah diterapkan. Pertama peserta didik saat datang ke sekolah salam dengan guru dan berjabat tangan dengan guru, lonceng (tamborin) lalu peserta didik berbaris dihalaman sekolah akan dilaksanakannya upacara bendera hari senin lalu berbaris rapih sebagai penanaman karakter disiplin, upacara bendera lalu peserta didik menyanyikan lagu "ayo berbaris", peserta didik selalu dibiasakan senam pagi, Pertama dengan pembukaan berdoa sebelum kegiatan, setelah itu guru mengajak peserta didik untuk menyanyi.

3. Evaluasi yang digunakan dalam pembentukan karakter disiplin, Tanggung Jawab dan kemandirian Di TK A Kota Cimahi

Berdasarkan pemaparan hasil studi dokumentasi di atas maka dapat disimpulkan bahwa guru TK A telah berusaha semaksimal mungkin dalam mengenalkan buruk dan baik untuk pengembangan nilai-nilai di kelas TK A. sehingga dapat terlihat terjadi perubahan/peningkatan proses pembentukan karakter disiplin, Tanggung Jawab dan kemandirian melalui program pembiasaan dan keteladanan dan indicator pencapaian perkembangan yang sesuai dengan rentang usia peserta didik sehingga proses pembentukan karakter disiplin, tanggung, dan kemandirian melalui program pembiasaan dan keteladanan dapat dengan berkembang dengan optimal.

\section{Kesimpulan}

Di TK A sudah terbentuk nya pembentukan karakter disiplin, tanggung jawab dan kemandirian melalui pembiasaan dan keteladanan . peserta didik melakukan penerapan pembiasaan dan keteladanan pada setiap hari disekolah.

\section{Daftar Pustaka}

[1] Ahmad Muhaimin Azzet. (2011). Urgensi Pendidikan Karakter Di Indonesia Revitalisasi Pendidikan Karater terhadap Keberhasilan Belajar dan Kemajuan Bangsa. Yogyakarta: Ar-Ruzz Media.

[2] Citra Umbara. UNDANG-UNDANG RI NO 20 TAHUN 2003. Bandung: Citra Umbara.

[3] Megawangi, Ratna. (2004). Pendidikan Karakter. (Cetakan Pertama). Jakarta: Indonesia Heritage Foundation.

[4] Yaumi, M. (2014). Pendidikan Karakter. (landasan, pilar, dan implementasi). Jakarta: Prenadamedia Group.

[5] Nizar, I A I. 2009, Membentuk dan Meningkatkan Disiplin Anak Sejak Dini. Jogjakarta: Diva press.

[6] Thomas, Lickona. (2012) character matters. Jakarta: Bumi Aksara.

[7] https://eprints.umc.ac.id

[8] https://eprints.iain-surakarta.ac.id 